\title{
Amelioration of Cisplatin-induced Liver Injury by Extract Ethanol of Pometia pinnata
}

\author{
Adrian Adrian ${ }^{1}$, Rony Abdi Syahputra ${ }^{2 *}$ D, Sukirman Lie ${ }^{1}$, Sony Eka Nugraha ${ }^{3}$ \\ ${ }^{1}$ Department of Biomedicine, Faculty of Medicine, Universtas Prima, Medan, Indonesia; ${ }^{2}$ Department of Pharmacology, Faculty \\ of Pharmacy, Universitas Sumatera Utara, Medan, Indonesia; ${ }^{3}$ Department of Pharmaceutical Biology, Faculty of Pharmacy, \\ Universitas Sumatera Utara, Medan, Indonesia
}

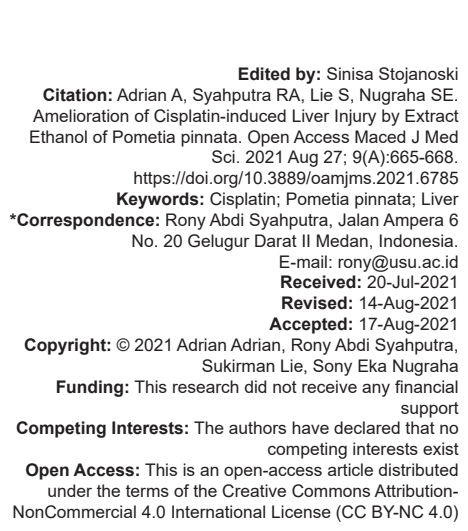

\section{Introduction}

Cisplatin is a chemotherapeutic medication that is frequently used to treat cancers of the bladder, lung, ovary, and testicle. In addition, it is known to be highly powerful against cancer. Cisplatin inhibits mitosis and induces apoptosis through oxidative stress and crosslinking with cancer DNA. Cisplatin kills cancer cells by generating DNA adducts that prevent cancer cells from entering the $\mathrm{G} 2$ cell cycle and inducing apoptosis. Although Cisplatin has been known effective in killing cancer cells clinically, it can be hazardous to the kidneys, liver, brain, and heart. The use of higher doses and recurrent administration raises the risk of organ damage in a variety of organs. Cisplatin can generate reactive oxygen species (ROS), which can result in liver apoptosis. ROS are extremely reactive molecules that can activate superoxide radicals, hydroxyl radicals, and hydrogen peroxide, which can damage lipids, proteins, and DNA in the body. Cisplatin may induce lipid peroxidation, which may contribute to liver damage. Cisplatin use in clinical practice has been associated with an increase in serum aspartate aminotransferase
(AST), alanine aminotransferase (ALT), alkaline phosphatase, and lactate dehydrogenase (LDH). The increase in serum indicators indicates the possibility of liver injury when Cisplatin is used [1], [2], [3], [4], [5]

Endogenous antioxidants such as superoxide dismutase (SOD), glutathione, and catalase play a critical role in neutralizing ROS generated by Cisplatin. When Cisplatin is used, an imbalance between endogenous antioxidants and ROS is created; when there is more ROS, the ROS are more capable of causing organ damage. As a result, when Cisplatin is used, extra supplements or chemicals that boost endogenous antioxidants are required. One method is to administer herbal treatment to individuals receiving Cisplatin. Pometia pinnata is a widely cultivated plant in Papua, Indonesia. The Papuan people have traditionally employed the bark, stems, fruit peels, fruits, and leaves of $P$. pinnata as medicine. However, research on $P$. pinnata is still in its infancy; few studies have been conducted on the $P$. pinnata plant. Numerous investigations have revealed that $P$. pinnata possesses a variety of pharmacological properties, including antidiabetic, anti-inflammatory, and antihyperlipidemic properties. P. pinnata also includes flavonoids such 
as quercetin, rutin, and myristate, which are known to have a variety of pharmacological properties, including hepatoprotective activity. In addition, previous study has showed that $P$. pinnata exhibits substantial antioxidant activity when measured using the 2,2-diphenyl-1picrylhydrazyl (DPPH) method, with an $\mathrm{IC}_{50}<50$ ppm indicating that it exhibits strong antioxidant activity. Due to $P$. pinnata has high antioxidant activity, it is projected that this plant possesses a variety of pharmacological properties, including hepatoprotective properties [6], [7], [8], [9].

Thus, this study contributes novelty information about the hepatoprotective efficacy of an ethanol extract of $P$. pinnata in Cisplatin-induced mice.

\section{Method}

\section{Materials}

Cisplatin purchased from Kimia Farma (Indonesia), Ethanol purchased from Bratachem (Indonesia), DPPH purchased from Sigma Aldrich (Germany), Water pro injection purchased from Bratachem (Indonesia), Vitamin C purchased from Sigma Aldrich (Germany), Gallic Acid purchased from Sigma Aldrich (Germany), Folin-Ciocalteu purchased from Sigma Aldrich (Germany), Quercetin purchased from Sigma Aldrich (Germany), Cisplatin purchased from Kimia Farma (Indonesia).

\section{Animal}

The experimental study used thirty rats (Rattus norvegicus) in good health and weighing between 150 and $200 \mathrm{~g}$. Rats are housed in plastic cages with a humidity level of $40-60 \%$ and a 12-h dark/light cycle. In addition, rats were given cratachem producing pellet diet and water ad libitum. The University of North Sumatra had granted ethics clearance for this project.

\section{Plant}

Pometia pinata was collected in Papua, cleaned, dried, and then blended till a dry powder was formed. In addition, the powder obtained was stored at room temperature and opened as needed.

\section{Extract preparation}

Seven hundred grams of dried powder $P$. pinnata was dissolved in $96 \%$ ethanol and then steered occasionally; the solution was then macerated for 7 days and steered occasionally each day; the solution was then filtered using Whatman paper no 1 , and the results were filtered (EEPE). Following that, phytochemical screening (alkaloids, flavonoids, tannins, saponins, glycosides, and steroids/triterpenoids) is performed [10], [11].

\section{Experimental design}

Thirty rats were separated into six groups of five each. Group I was a control group in which rats received only carboxy methyl cellulose. Group II was a negative control group in which rats received a $7 \mathrm{mg} / \mathrm{kgbw}$ Cisplatin injection on day 3. Group III was a positive group in which rats were administered $1 \%$ Vitamin C for 7 days and then injected with Cisplatin on day 3. Groups IV-VI were extract groups (100 mg/kgbb, $200 \mathrm{mg} / \mathrm{kgbb}$, $400 \mathrm{mg} / \mathrm{kgbb}$ ) in which rats were administered extract orally from day 1 to day 7 , followed by Cisplatin injection on day 3 . On day 8 , rats were injected with $1 \%$ ketamine, which draws blood directly from the heart.

\section{Biochemical parameters measurement}

Three milliliters of blood from each rat was centrifuged at $4000 \mathrm{RPM}\left(50^{\circ} \mathrm{C}\right)$ for $10 \mathrm{~min}$, and then $0.5 \mathrm{~mL}$ of the supernatant was extracted and directly injected into a Cobas 6000 (Swiss company Roche Diagnostic) for the determination of AST, ALT, total protein, and $\mathrm{LDH}$.

\section{Data analysis}

Statistical package for social science program 21 was used to analysis of the data. Data are expressed as Mean SEM. Comparison for more than 2 groups using one-way ANOVA followed by post-hoc tukey. Statistical significance was set at $p<0.05$.

\section{Results}

\section{Analysis of AST and ALT levels}

AST and ALT levels are the key indicators of liver injury; higher levels of AST and ALT are directly proportional to liver damage; hence, when AST and ALT levels rise, liver damage will also worsen. Cisplatin produced liver injury in this investigation, as indicated by the AST and ALT levels in Table 1 below.

Table 1: Data values for AST and ALT (U/L)

\begin{tabular}{lll}
\hline Groups & Mean AST (U/L) & ALT (U/L) \\
\hline Group 1 & $35.36 \pm 1.521$ & $40.51 \pm 2.731$ \\
Group 2 & $125.12 \pm 10.873 *$ & $105.67 \pm 10.484 *$ \\
Group 3 & $32.67 \pm 1.73$ & $38.45 \pm 1.937$ \\
Group 4 & $86.38 \pm 3.83$ & $78.62 \pm 5.873$ \\
Group 5 & $65.44 \pm 2.44$ & $58.12 \pm 3.88$ \\
Group 6 & $42.21 \pm 2.01 \#$ & $38.43 \pm 1.89 \#$ \\
\hline Information: group 1 (normal), group 2 (Cisplatin only), group 3 (Cisplatin + Vit C), group 4 (Cisplatin + \\
100 mg/kgbw), group 5 (Cisplatin + 200 mg/kgbw), group 6 (Cisplatin + 400 mg/kgbw). * $(\mathrm{p}<0,05)$ significant \\
different from normal group. \#( $(\mathrm{p}<0,05)$ significant different from group 2. AST: Aspartate aminotransferase, \\
ALT: Alanine aminotransferase.
\end{tabular}


The effect of extract ethanol of $P$. pinnata on liver biochemical markers such as AST and ALT is shown in Table 1. Group 2 had a significant increase $(p<0.05)$ in comparison to the group 1 that did not receive extract or Cisplatin. Meanwhile, there was a drop in biochemical parameters in the group given the extract in groups 4, 5, and 6. In group 6 statistically, there is no significant difference with group 1 ( $p>0.05)$ owing to the $P$. pinnata leaf extract's high antioxidant activity, which conferred hepatoprotective action.

\section{Analysis of $L D H$ and total protein levels}

LDH is a critical enzyme in the anaerobic metabolic pathway that belongs to the oxidoreductase class; an increase in LDH levels indicates an increase in lactate levels, particularly in muscles; an increase in $\mathrm{LDH}$ levels in an organ also signals organ damage. Total protein is also used to determine the extent of liver damage. Data are included in Table 2 below.

Table 2: Data values for LDH (U/L) and total protein (g/dL)

\begin{tabular}{lll}
\hline Groups & Mean LDH $(\mathrm{U} / \mathrm{L})$ & Total protein $(\mathrm{g} / \mathrm{dL})$ \\
\hline Group 1 & $186.4 \pm 12.873$ & $4.62 \pm 0.218$ \\
Group 2 & $856.76 \pm 21.98^{*}$ & $8.56 \pm 0.183^{*}$ \\
Group 3 & $201.32 \pm 12.83$ & $4.65 \pm 0.213$ \\
Group 4 & $455.4 \pm 10.31$ & $5.66 \pm 0.381$ \\
Group 5 & $324.6 \pm 12.57$ & $5.21 \pm 0.478$ \\
Group 6 & $188.24 \pm 9.38 \#$ & $4.82 \pm 0.229 \#$ \\
\hline Information: group 1 (normal), group 2 (Cisplatin only), group 3 (Cisplatin + Vit C), group 4 (Cisplatin + 100 mg/ \\
kgbw), group 5 (Cisplatin + 200 mg/kgbw), group 6 (Cisplatin + 400 mg/kgbw). * $(\mathrm{p}<0,05)$ significant different
\end{tabular}

from normal group. \#( $(<<0,05)$ significant different from control group 2 . LDH: Lactate dehydrogenase.

The effect of extract ethanol of $P$. pinnata on liver biochemical markers such as LDH and total protein is shown in Table 2. Group 2 had a significant increase $(p<0.05)$ in comparison to the Group 1 that did not receive extract or Cisplatin. Meanwhile, there was a drop in biochemical parameters in the group given the extract in groups 4,5 , and 6 . In Group 6 statistically, there is no significant difference with Group 1 ( $p>0.05$ ) owing to the $P$. pinnata leaf extract's high antioxidant activity, which conferred nephroprotective action.

\section{Discussion}

The highest level of AST and ALT can be found in the Group 2 that only injected cisplatin on day 3 which are $125.12 \pm 10.873 \mathrm{U} / \mathrm{L}$ and $105.67 \pm$ $10.484 \mathrm{U} / \mathrm{L}$, while in the Group 6 that given $P$. pinnata extract dose $400 \mathrm{mg} / \mathrm{kgbw}$ showed the reduction of the AST and ALT level which are $42.21 \pm 2.01 \mathrm{U} / \mathrm{L}$ and $38.43 \pm 1.89 \mathrm{U} / \mathrm{L}$. The significant antioxidant activity of extract ethanol of $P$. pinnata demonstrates the extract's ability to diminish the ROS produced by Cisplatin. Antioxidants are found in abundance in plants; therefore, if the antioxidant capacity of the extract is high, the extract may have additional pharmacological activities such as anticancer, as the inhibitory pathway against cancer cells is generally to increase the expression of endogenous antioxidants such as SOD, GSH, CAT, and GPX. In addition, the antioxidants in the extract may enhance the ability of endogenous antioxidants in the body to neutralize ROS such as $\mathrm{OH}-, \mathrm{H}_{2} \mathrm{O}_{2}$, and $\mathrm{O}$-. Of course, antioxidants can also protect cells from free radicals. Flavonoids are secondary metabolites found in plants that exhibit antioxidant action. Their activity is largely reliant on the group's location of free $\mathrm{OH}$. Earlier research indicated that the ethanolic extract of matoa leaves contained $1.9 \%$ flavonoids. Differences in total flavonoid output may be a result of genetic diversity and seasonality in the environment, both of which affect flavonoids in these plants [12], [13].

The highest level of LDH and total protein can be seen in the Group 2 that only injected cisplatin which is $856.76 \pm 21.98 \mathrm{U} / \mathrm{L}$ and $856.76 \pm 21.98 \mathrm{~g} / \mathrm{dL}$ while in the group given extract dose $400 \mathrm{mg} / \mathrm{kgbw}$ showed significant reduction of LDH and total protein level which are $188.24 \pm 9.38 \mathrm{U} / \mathrm{L}$ and $4.82 \pm 0.229 \mathrm{~g} / \mathrm{dL}$. Cisplatin buildup in the liver and drug metabolic abnormalities can result in liver damage. Genetic or hereditary liver illness, such as hemochromatosis, a condition of iron metabolism characterized by excessive iron deposition in the organs. Immune disorders, such as autoimmune hepatitis, are diseases caused by the body's own tissues developing resistance. In general, in autoimmune hepatitis, the liver cells are at odds, resulting in persistent inflammation [14], [15], [16], [17]. AST and ALT are two transaminases that are mostly produced by liver cells. When liver cells are destroyed, as in hepatitis or cirrhosis, these two enzymes typically increase in concentration. Both are believed to provide a picture of a liver illness based on the findings of laboratory tests. Liver illnesses characterized by a marked increase in AST and ALT levels are hepatocellular in origin. ALT is more sensitive than AST at detecting viral hepatitis in general. In alcoholic liver disease, the AST level is two or more times that of the ALT [18], [19], [20], [21]. In many studies shows that cisplatin increases the level of liver biochemical injury such as blood urea nitrogen, AST, MDA, and creatinine while reduce the level of endogenous antioxidant such as SOD, glutathione, and catalase. Cisplatin also increases hepatic inflammatory such as tumor necrosis factor $\alpha$ and nuclear factor erythroid 2-related factor 2 (NRF-2). This study was in line with previously study that stated Cisplatin can damage the liver by increasing apoptosis which causes increasing levels of biochemical parameters [22], [23]. This study still has limitations because of lack of parameters analysis but the primer information regarding the ability of $P$. pinnata extract can be valuable for further research. 


\section{Acknowledgments}

The authors express their profound gratitude and appreciations to the Faculty of Pharmacy, Universitas Sumatera Utara and Universitas Prima Indonesia for supporting this research.

\section{References}

1. Breglio AM, Rusheen AE, Shide ED, Fernandez KA, Spielbauer KK, McLachlin KM, et al. Cisplatin is retained in the cochlea indefinitely following chemotherapy. Nat Commun. 2017;8(1):1654. https://doi.org/10.1038/s41467-017-01837-1 PMid:29162831

2. Zhang $Y$, Chen $L$, Hu GQ, Zhang $N$, Zhu $X D$, Yang $K Y$, et al. Gemcitabine and cisplatin induction chemotherapy in nasopharyngeal carcinoma. N Engl J Med. 2019;381(12):1124-35. PMid:31150573

3. Makovec T. Cisplatin and beyond: Molecular mechanisms of action and drug resistance development in cancer chemotherapy. Radiol Oncol. 2019;53(2):148-58. https://doi. org/10.2478/raon-2019-0018

PMid:30956230

4. Un H, Ugan RA, Kose D, Bayir Y, Cadirci E, Selli J, et al. A novel effect of aprepitant: Protection for cisplatin-induced nephrotoxicity and hepatotoxicity. Eur J Pharmacol. 2020;880:173168. https://doi.org/10.1016/j.ejphar.2020.173168 PMid:32423870

5. Khan MW, Zhao P, Khan A, Raza F, Raza SM, Sarfraz M, et al. Synergism of cisplatin-oleanolic acid co-loaded calcium carbonate nanoparticles on hepatocellular carcinoma cells for enhanced apoptosis and reduced hepatotoxicity. Int J Nanomed. 2019;14:3753-71. https://doi.org/10.2147/ijn.s196651 PMid:31239661

6. Naidi SN, Khan F, Tan AL, Harunsani MH, Kim YM, Khan MM Photoantioxidant and antibiofilm studies of green synthesized Sn-doped $\mathrm{CeO}_{2}$ nanoparticles using aqueous leaf extracts of Pometia pinnata. N J Chem. 2021;45(17):7816-29. https://doi. org/10.1039/d1nj00416f

7. Irawan C, Sulistiawaty L, Rochaeni H, Lestari PS. Evaluation of DPPH free radical scavenging activity of Pometia pinnata from Indonesia. Pharma Innov. 2017;6(8):403-6.

8. Rohmawati D, Sutoyo S. Steroid isolated from the dichlorometane extract of matoa's stem bark (Pometia pinnata) and toxicity tests against Artemia salina Leach. In: Proceedings of the Seminar Nasional Kimia-National Seminar on Chemistry. Vol. 2. Netherlands: Atlantis Press; 2018. p. 187. https://doi. org/10.2991/snk-18.2018.25

9. Prihanti GS, Katjasungkana RM, Novitasari BR, Amalia SR, Nurfajriana A, Agustini SM, et al. Antidiabetic potential of matoa bark extract (Pometia pinnata) in alloxan-induced diabetic male rat strain wistar (Rattus norvegicus). Syst Rev Pharm. 2020;11(8):88-97.

10. Nugraha SE, Yuandani ES, Syahputra RA. Investigation of phytochemical constituents and cardioprotective activity of ethanol extract of beetroot (Beta vulgaris. L) on doxorubicin induced toxicity in rat. Rasayan J Chem. 2020;13(2):973-8. https://doi.org/10.31788/rjc.2020.1325601

11. Syahputra RA, Harahap U, Dalimunthe A, Nasution P, Haro G, Widodo $\mathrm{DH}$, et al. In silico toxicity prediction of bioactive compounds of Vernonia amygdalina Delile. and digoxin. Rasayan J Chem. 2020;13(2):1220-4. https://doi.org/10.31788/ rjc.2020.1325638

12. Bazmandegan G, Amirteimoury M, Kaeidi A, Shamsizadeh A, Khademalhosseini $\mathrm{M}$, Nematollahi $\mathrm{MH}$, et al. Sumatriptan ameliorates renal injury induced by cisplatin in mice. Iran J Basic Med Sci. 2019;22(5):563-7.

PMid:31217938

13. Sioud F, Toumia IB, LahmerA, Khlifi R, Dhaouefi Z, Maatouk M, et al Methanolic extract of Ephedra alata ameliorates cisplatin-induced nephrotoxicity and hepatotoxicity through reducing oxidative stress and genotoxicity. Environ Sci Pollut Res. 2020;27(11):12792-801. https://doi.org/10.1007/s11356-020-07904-3 PMid:32008195

14. Niu C, Ma M, Han X, Wang Z, Li H. Hyperin protects against cisplatin-induced liver injury in mice. Acta Cir Bras. 2017;32(8):633-40. https://doi.org/10.1590/ s0102-865020170080000005 PMid:28902939

15. Ekinci-Akdemir FN, Bingöl Ç, Yıldırım S, Kandemir FM, Küçükler S, Sağlam YS. The investigation of the effect of fraxin on hepatotoxicity induced by cisplatin in rats. Iran J Basic Med Sci. 2020;23(11):1382-7. PMid:33235694

16. El-Gizawy MM, Hosny EN, Mourad HH, Abd-El Razik AN. Curcumin nanoparticles ameliorate hepatotoxicity and nephrotoxicity induced by cisplatin in rats. Naunyn Schmiedebergs Arch Pharmacol. 2020;393(10):1941-53. https://doi.org/10.1007/s00210-020-01888-0

PMid:32447466

17. MohamedHE,BadawyMM.Modulatoryeffectofzingeroneagainst cisplatin or $\gamma$-irradiation induced hepatotoxicity by molecular targeting regulation. Appl Radiat Isot. 2019;1(154):108891. https://doi.org/10.1016/j.apradiso.2019.108891

PMid:31536909

18. Jarsiah $P$, Nosrati A, Alizadeh A, Hashemi-Soteh SM Hepatotoxicity and ALT/AST enzymes activities change in therapeutic and toxic doses consumption of acetaminophen in rats. Int Biol Biomed J. 2017;3(3):119-24.

19. Mansour DF, Saleh DO, Mostafa RE. Genistein ameliorates cyclophosphamide-induced hepatotoxicity by modulation of oxidative stress and inflammatory mediators. Open Access Maced J Med Sci. 2017;5(7):836-43. https://doi.org/10.3889/oamjms.2017.093 PMid:29362606

20. Roh T, De U, Lim SK, Kim MK, Choi SM, Lim DS, et al. Detoxifying effect of pyridoxine on acetaminophen-induced hepatotoxicity via suppressing oxidative stress injury. Food Chem Toxicol. 2018;114:11-22. https://doi.org/10.1016/j.fct.2018.02.017 PMid:29438775

21. Goodarzi Z, Karami E, Yousefi S, Dehdashti A, Bandegi AR, Ghanbari A. Hepatoprotective effect of atorvastatin on cadmium chloride induced hepatotoxicity in rats. Life Sci. 2020;254:117770. https://doi.org/10.1016/j.lfs.2020.117770 PMid:32407846

22. Omar HA, Mohamed WR, Arab HH, Arafa ES. Tangeretin alleviates cisplatin-induced acute hepatic injury in rats: Targeting MAPKs and apoptosis. PLoS One. 2016;11(3):e0151649. https://doi.org/10.1371/journal.pone.0151649 PMid:27031695

23. Hassan HM, Al-Wahaibi LH, Elmorsy MA, Mahran YF. Suppression of cisplatin-induced hepatic injury in rats through alarmin high-mobility group box-1 pathway by Ganoderma lucidum: Theoretical and experimental study. Drug Des Dev Ther. 2020;14:2335-53. https://doi.org/10.2147/dddt.s249093 PMid:32606602 